\title{
Measuring E-Service Quality and Customer Satisfaction with Internet Banking in India
}

\author{
Sindhu Singh \\ K. J. Somaiya Institute of Management Studies and Research, Mumbai, India \\ Email: sindhusingh@ somaiya.edu
}

How to cite this paper: Singh, S. (2019) Measuring E-Service Quality and Customer Satisfaction with Internet Banking in India. Theoretical Economics Letters, 9, 308-326. https://doi.org/10.4236/tel.2019.92023

Received: November 9, 2018

Accepted: February 22, 2019

Published: February 25, 2019

Copyright $\odot 2019$ by author(s) and Scientific Research Publishing Inc. This work is licensed under the Creative Commons Attribution International License (CC BY 4.0).

http://creativecommons.org/licenses/by/4.0/

\section{c) (i) Open Access}

\begin{abstract}
The objective of this study is to measure the e-service quality of internet banking and the relationship with customer satisfaction in India. This study aims to explore the critical factors of e-service quality of internet banking in India and to measure the customers' satisfaction of internet banking on the identified e-service quality dimensions. A survey method was carried out to acquire data from 650 respondents from India. Exploratory and confirmatory factor analysis was used to identify the dimensions of internet banking. Multiple Regression Analysis was used to test the relationship with e-service quality dimensions and customer satisfaction of internet banking. The study uncovered three factors of e-service quality, namely, "Responsiveness," "Efficiency," and "Perceived Credibility". "Responsiveness" found to be the most significant predictor of the e-service quality of internet banking. The study also found that there is a positive relationship exists between e-service quality dimensions and customer satisfaction of internet banking. These findings can be used by banks to improve the service quality of their internet banking service and thereby to satisfy their customers. The findings open up many business opportunities to India as well as other Asian countries. The digital payments industry can concentrate on improving the security of the payment systems, gateways, and payment networks. Advanced technologies can be developed to improve the digital payment systems which offer many business opportunities for creating computers, smartphones, and innovation in internet and security software. The study findings can be used by banks to improve the service quality of internet banking and attract more customers towards using this service. The improvement in service quality comprising of responsiveness, efficiency, and perceived credibility automatically leads to the customer satisfaction of internet banking services, which gives competitive advantages to the banks. This study is an attempt to cover both urban and rural population of India to understand the digital mindset by studying the quality perception of internet banking channel.
\end{abstract}




\section{Keywords}

Internet Banking, Service Quality, India, Responsiveness, Efficiency

\section{Introduction}

The Internet and wireless technologies have revolutionized the entire world and transformed business. According to a report by [1], Internet penetration reached 4.2 billion globally by the end of June 2018, with India (ranked second worldwide), reaching 462 million internet users as of March 2017. Banks are embracing diverse communications technologies through the Internet in order to offer wide-ranging services to their customers to meet customers' expectations, endure the competitive environment, reduce costs and increase customer convenience. Internet banking experienced tremendous growth in both developed and developing countries and reshaped banking activities. Internet banking allows customers to access banking services online without visiting bank branches. Also known as e-banking or online banking, it uses the Internet as the delivery channel to offer banking products to its customers [2]. Digital payments like internet banking will be part of everyone's day to day life due to any time any where features and on the go purchasing habits with the surging increase of e-commerce transactions. Besides that, the service-delivery process for internet banking, in which the customer interacts with the bank's website, is very different from traditional brick-and-mortar service of banking operations [3] [4] [5]. Offering customers the ability to view transaction details, transfer funds, pay utility bills, or shop online [3] [6], it has transformed the traditional "brick-and-mortar"1 approach into a "click-and-mortar" model [8]. ICICI Bank was the first bank to introduce internet banking to India, in 1996 [9].

As per the report of [10], 13\% of consumer payments contributed by digital payments including internet banking. India is at present into the demonetization stage, and the Government of India is increasing its cashless transactions. In the present scenario, Indian bank customers are compelled to make greater use of digital payment systems. More and more digital payment systems are entering the Indian economy. In order to stay competitive, therefore, it is essential for banks in India to improve the quality of their internet banking systems so that more users will use this channel for their digital transactions. The use of Internet banking in India is more developed in urban areas than in rural areas. Currently, $44 \%$ of customers are using internet banking, and it is one of the preferred modes of digital payment [11]. Increased use of Internet banking will enhance customer expectations and perceptions regarding the quality of this new delivery channel. In this regard, it is vital to understand how to measure the service quality of Internet banking in India, as well as customer satisfaction with it. Aware-

${ }^{1}$ The expression "brick and mortar" is defined as "based on a physical store where the vendor interacts with the customer" [7].

${ }^{2}$ The expression "click and mortar" refers to a scenario in which both online and offline operations, i.e., both a website and a physical store (Wikipedia). 
ness of how customers perceive service quality is essential to understanding what customers' value in an online transaction. It is also essential to attracting new customers and retaining existing customers. Limited studies are there in the literature which embraces a rural and urban population of India measuring the service quality dimensions of internet banking. This study aims to identify the e-service quality dimensions and determine their impact on customers' satisfaction with internet banking. The level of this customer satisfaction, which is influenced by the e-service quality, will play a significant role in determining the continued use of internet banking. The significant theoretical contribution of this study is to identify the service quality dimensions and its relationship with customer satisfaction in Indian banking context by mounting the prior literature in internet banking service quality. The practical contributions of this study will help the banks to improve the service quality of internet banking services, which will increase the satisfaction level and continued use of this service. The quality attributes identified from this study can be used to improve the internet banking products of their banks.

The structure of the paper is as follows. The first section describes the literature review which discusses the e-service quality, e-service quality of internet banking and customer satisfaction. Next, the second section explains the hypotheses development and the third section describes the research methodology used in this paper. The fourth section mentions the findings of this study and the fifth section discusses the theoretical and practical implications of this study. Finally, the limitations and future research directions are discussed.

\section{Literature Review}

\subsection{E-Service Quality}

Electronic service quality plays a crucial role in attracting and retaining customers in the business to consumer (B2C) e-commerce environment. [12] Defined e-service quality as "the extent to which a website facilitates efficient and effective shopping, purchasing and delivery of product and services." [13] Defined e-service quality as "the degree to which an electronic service is able to effectively and efficiently fulfill relevant customer needs." [14] Defined e-service quality as "the consumer's evaluation of process and outcome quality of the interaction with a service provider's electronic channels." The conventional SERVQUAL scale was initially applied to the online environment to measure e-service quality, which had raised many criticisms [15] [16]. The main difference between the traditional service environment and the e-service environment is the absence of personal interaction between the customers and the employees within an e-service firm which leads to the measurement of e-service quality. The initial studies of e-service quality were more concentrated on website quality than on service quality in the online environment [17]-[23]. [12] developed an e-service quality scale consisting of five dimensions: information availability, ease of use, privacy/security, graphics style, and reliability. [24] conceptualized and constructed a multiple-item scale consisting of seven dimensions for meas- 
uring the service quality delivered by websites. These seven dimensions were subdivided into two scales consisting of E-S-QUAL and E-RecS-QUAL. E-SQUAL [24] is a 22-item scale, with four dimensions: efficiency, system availability, fulfillment and privacy. The E-RecS-QUAL [24] is an eleven-item scale of three dimensions: responsiveness, compensation, and contact, focusing on handling service problems and inquiries.

\subsection{E-Service Quality of Internet Banking}

Internet banking is one of the narrowly defined e-services in the virtual environment. Internet banking transformed traditional brick-mortar branching services. In the absence of geographical constraints and personal interaction between customers and bank employees, attracting and retaining customers largely depends on the service quality of internet banking.

Prior studies on service quality of internet banking identified various service quality dimensions using various e-service quality scales. Among these studies, some of the researchers used the SERVQUAL scale [25] [26], WebQual 4.0 scale [27] and some studies used e-SERVQUAL [28] [29] within the internet banking context. Few researchers classified the service quality dimensions of internet banking as customer service quality, banking service product quality and online system quality [30] [31] [32].

In addition, prior studies identified some of the key dimensions of internet banking service quality as reliability [26] [30] [33] [34], responsiveness [26] [32] [33] [35] [36], trust [25] [37] [38], web interface [25] [38] [39] [40] [41], efficiency [28] [36] [42], security [28] [35], and fulfilment [29] [36].

The review of the studies mentioned above reveals that the various studies have considered various dimensions and measurement scales. They show that there have been a multiplicity of constructs for measuring e-service quality and those researchers are still grappling over which construct best represent the e-service quality of internet banking. There are very few studies that cover the urban and rural population of India.

\subsection{Customer Satisfaction}

Satisfaction, according to [43] perspective is "an on-going evaluation of the surprise inherent in a product acquisition and/or consumption experience." [44] Defined e-satisfaction as "the contentment of the customer with respect to his or her prior purchasing experience with a given electronic-commerce firm." In their IS research, [45] described user satisfaction as covering "the entire customer experience cycle from information retrieval through purchase, payment, receipt, and service."

\section{Hypotheses Development}

\section{Relationship with E-Service Quality and Customer Satisfaction}

Existing studies have found that there is a positive relationship between service 
quality and satisfaction [12] [46] [47] [48] [49] [50]. The positive or negative consumer perceptions of e-service quality of internet banking led to satisfaction (or dissatisfaction) with the internet banking services provided by the banks. Past studies of internet banking empirically proved that the customers' overall satisfaction with internet banking depends on the quality of internet banking services provided to the customers [26] [42]. Hence, the following hypothesis is proposed:

$\mathrm{H} 1$ : Internet banking service quality has a positive influence on customer satisfaction with internet banking.

\section{Research Methodology}

This study uses a cross-sectional design, which involved the collection of information from the sample only once. It uses a quantitative data collection method, employing a structured questionnaire to collect responses from existing bank customers. A survey questionnaire was used to administer data collection for identifying the e-service quality of internet banking and its relationship with customer satisfaction. In this study, the e-service quality of internet banking was measured using the following dimensions: access, web interface, attention and credibility from the [25] scale, which was a modified version of the original SERVQUAL [51], scale. These dimensions were chosen because they are the dimensions used by past studies to measure the e-service quality of internet banking [2] [26] [28] [29] [33] [34] [35] [36] [38] [40] [41] [42]. Dimension access refers to empowering "customers to utilize the service through some points of entry and the ability to carry out a wide range of transactions." The web interface is "maintenance of a website that enhances the overall browsing experience of customers." Attention is the "provision of accurate, personalized service to customers." Credibility refers to "delivering the promised service to customers at all times." Variable customer satisfaction is measured using five items adapted from [52]. A total of 19 items were used to capture respondent views about e-service quality and their satisfaction with internet banking. The present study uses a 7-point Likert scale from $1-7$, where $1=$ strongly disagree and $7=$ strongly agree since it is easy to specify the intended meanings of points with words and maximizes reliability and validity [53] for collecting the response from bank customers. The adapted scales were reworded to fit the need for the current study. These scales had shown reliability and validity in the studies from which they were adopted. Reliability and validity tests were conducted to verify the suitability of the adapted scales used in the present study. Cronbach Alpha was used to calculate the reliability of the constructs used in this study and only items having a Cronbach Alpha value of 0.7 or more were used [54]. Content validity had been ensured by adapting the constructs from prior validated studies based on well-accepted theoretical models. Construct validity was established through exploratory factor analysis. The questionnaire was shown to academicians in the IS and marketing fields, as well as practitioners to test the initial instrument for measurability, context and respondent's perceptions of the topic of 
the current study. The questionnaire was pre-tested by collecting responses from five internet banking consumers and five non-internet banking consumers to check the wording, sequencing, and completeness. Based on the feedback from respondents, the sequencing of the questionnaire was modified, ambiguous questions were deleted, and some of the wording was changed as needed. The feedback received from both groups is incorporated into the questionnaire to improve its clarity, relevance, and consistency and the questionnaire was revised after pre-testing.

The target population identified for this study was the bank customers who have operational bank accounts from various public, private, co-operative and foreign banks in India. The population group of bank centers was classified as rural, semi-urban, urban and metropolitan, based on the population of the centers was available in the 2001 census of India. This research study used convenience sampling, a non-probability sampling method, as the choice for selecting the respondents to collect the sample elements. Convenience sampling was chosen as a method of collecting responses from the survey questionnaire because of the unavailability of the total banking customer list and the expense and time required to collect responses from every bank customer. The choice of respondents was particular, limited to computer literate individuals who use internet banking. A total of 1000 questionnaires were distributed, using a combination of the self-administered method and by sending e-mail through personal contacts. Seven hundred completed questionnaires were collected from bank customers, of whom 650 were usable, for a response rate of $65 \%$. When the sample size becomes larger, it assures the confidence with which the estimates of the population can be obtained. In multivariate techniques like multiple regression analysis, the sample size should be at least ten times larger than the number of variables being considered [54]. The minimum sample size required for SEM (Structural Equation Model) analysis is 200 [54]. Hence, the sample size was considered robust by [55], as cited by [56].

The survey-based research is liable to common method variance where respondents fill out the survey questionnaire themselves [57]. Harman's single-factor test was conducted to examine the common method bias. An exploratory factor analysis was conducted with all the items of the measured constructs, and the results showed that more than one factor with eigen value greater than one was extracted and no single factor accounted major variance. Hence, common method bias was not a concern in this study.

The primary data collected from the questionnaire were tabulated and analyzed using SPSS (Statistical Package for Social Sciences) version 16.0. A reliability test was conducted using Cronbach Alpha to assess the internal consistency of the scales. The validity of the measures was conducted using exploratory and confirmatory factor analysis. Multiple regression analysis was used to measure the relationship between service quality dimensions and customer satisfaction. Confirmatory factor analysis using AMOS (Analysis of Moment Structures), 
version 16.0, was used to confirm the factor structure of the e-service quality dimensions of internet banking.

\section{Findings}

The demographic profile of the respondents (Table 1) includes gender, age, education, profession, and income. Of the total of 650 internet banking user respondents, the majority (72\%) were male, consistent with the earlier findings of internet banking usage [58] [59]. The majority of the respondents (64.2\%) were in the younger age group, between 20 to 29 years, indicating that adoption of innovative technologies like internet banking is more common among the younger population, which is consistent with past studies [60]. The majority of the respondents' educational qualifications were graduate (52\%), followed by post-graduate $(34.77 \%)$. This findings indicates that more educated people are more willing or able to use internet banking. The annual income of the majority of respondents falls between Rs. 1 lakh and Rs. 8 lakhs (43.85\%), whereas the highest annual incomes, i.e., Rs. 50 lakh and above, were reported by $1.23 \%$ of the respondents.

Among the respondents who are internet banking users $(\mathrm{N}=650), 38.3 \%$ use internet banking very often for their banking services (Table 2). The next highest frequency of usage is $37.1 \%$, who sometimes use internet banking for their banking services. The lowest usage percent age category is those who have an internet banking account but never use it (5.5\%). The results indicate that frequency of usage of internet banking is high in India, with customers preferring it as a convenient option enabling them to bank anytime and anywhere.

The descriptive statistics of the variables are presented in Table 3. The results show that the mean rating of all the variables were in the range of 5.17 and 5.88. Respondents rated all items above the neutral point 4 [54].

The multi-item scale is tested for reliability and validity. Exploratory factor analysis is conducted using principal component analysis as the extraction method and varimax as the rotation method to test the construct validity of the e-service quality scale.

The KMO and Barlett's test for the sphericity of internet banking service quality and satisfaction scale (Table 4) shows that the KMO value obtained is 0.917 indicates superb [61] verified the sampling adequacy of the analysis. Barlett's Test of sphericity $\chi^{2}(105)=4639.275, p=0.000(<0.05)$ indicates that the correlation matrix is not an identity matrix and the factor analysis is appropriate. The criteria to accept items are factor loadings greater than 0.5 [54]. A three-factor solution is found, accounting for a combined percent of 61.92 percent of the total variance explained.

The original scale adapted for the present study [25] did not factor out to the same dimensions. Some similarities and differences exist between the new factors and the original dimensions. The new factors emerged, and the factor loadings of each factor are provided in the following table (Table 5). 
Table 1. Demographic profile of the respondents.

\begin{tabular}{|c|c|c|c|}
\hline Variable & Category & Frequency & Percentage (\%) \\
\hline \multirow{2}{*}{ Gender } & Male & 468 & 72 \\
\hline & Female & 182 & 28 \\
\hline \multirow{6}{*}{ Age } & Below 20 & 8 & 1.20 \\
\hline & $20-29$ & 417 & 64.20 \\
\hline & $30-39$ & 122 & 18.77 \\
\hline & $40-49$ & 57 & 8.76 \\
\hline & $50-59$ & 35 & 5.38 \\
\hline & 60 -above & 11 & 1.69 \\
\hline \multirow{6}{*}{ Educational Qualification } & 10th & 6 & 0.92 \\
\hline & 12 th & 33 & 5.08 \\
\hline & Graduate & 338 & 52.00 \\
\hline & Postgraduate & 226 & 34.77 \\
\hline & Professional & 34 & 5.23 \\
\hline & $\mathrm{PhD}$ & 13 & 2.00 \\
\hline \multirow{4}{*}{ Profession } & Self-employed & 257 & 39.54 \\
\hline & Private Ltd & 253 & 38.92 \\
\hline & Public Sector & 71 & 10.92 \\
\hline & Multinational Co. & 69 & 10.62 \\
\hline \multirow{5}{*}{ Income } & Between Rs. 1-4 lakhs & 285 & 43.85 \\
\hline & Between Rs. 4-8 lakhs & 219 & 33.69 \\
\hline & Between Rs. 8-15 lakhs & 110 & 16.92 \\
\hline & Between Rs. 15-50 lakhs & 28 & 4.31 \\
\hline & Above 50 lakhs & 8 & 1.23 \\
\hline
\end{tabular}

Table 2. Frequency of internet banking usage.

\begin{tabular}{ccc}
\hline Frequency & No. of Users & Percentage \\
\hline Very Often & 249 & 38.3 \\
Sometimes & 241 & 37.1 \\
Rarely & 124 & 19.1 \\
Never & 36 & 5.5 \\
Total & 650 & 100.0 \\
\hline
\end{tabular}

Factor 1 is labeled "responsiveness," which includes support expected by the customer from the bank. The reliability statistic using Cronbach's Alpha obtained is 0.819 , which is above the accepted value of 0.7. Factor 2 is labeled "perceived credibility," which covers the security aspects of internet banking. The reliability statistic, obtained using Cronbach's Alpha, is 0.836, which is above the 
Table 3. Descriptive statistics of variables.

\begin{tabular}{|c|c|c|}
\hline Variables & Mean & Std. Deviation \\
\hline Customer needs & 5.43 & 1.16 \\
\hline Bank's accurate response & 5.36 & 1.22 \\
\hline Bank's personalized approach & 5.23 & 1.40 \\
\hline Help facility & 5.29 & 1.35 \\
\hline Get in touch with the bank & 5.43 & 1.25 \\
\hline Retrieval of information & 5.72 & 1.10 \\
\hline Account functionality & 5.73 & 1.17 \\
\hline Anytime Ibank login & 5.88 & 1.17 \\
\hline Anywhere Ibank login & 5.81 & 1.31 \\
\hline Unauthorized electronic fund transfer & 5.17 & 1.46 \\
\hline Others cannot view account info & 5.48 & 1.32 \\
\hline Webpage download & 5.39 & 1.27 \\
\hline Regular update & 5.51 & 1.18 \\
\hline The visual appeal of the website & 5.59 & 1.15 \\
\hline Service quality of I banking & 5.75 & 1.08 \\
\hline Good Online banking experience & 5.51 & 1.18 \\
\hline Satisfaction of bank & 5.70 & 0.93 \\
\hline Satisfaction of Ibanking & 5.68 & 1.04 \\
\hline Satisfaction of internet-based transactions & 5.88 & 0.95 \\
\hline
\end{tabular}

Table 4. KMOand Bartlett's Test of Internet Banking Service Quality and Satisfaction Scale.

\begin{tabular}{ccc}
\hline \multicolumn{2}{c}{ Kaiser-Meyer-Olkin Measure of Sampling Adequacy. } & 0.917 \\
\hline Bartlett's Test of Sphericity & Approx. Chi-Square & 4639.275 \\
& df & 105 \\
& Sig. & 0.000 \\
\hline
\end{tabular}

accepted value of 0.7 and above. Factor 3 is labeled "efficiency," which encompasses the convenience and competence of internet banking. The reliability statistic using Cronbach's Alpha is 0.843 which is above the accepted value of 0.70 and above.

The dimensionality of the e-service quality of internet banking scale obtained through exploratory factor analysis was examined using confirmatory factor analysis. Confirmatory factor analysis (CFA) was conducted to examine whether the measurement items of e-service quality of internet banking loaded by the pattern revealed in the exploratory factor analysis. The structural equation modeling (SEM) method using AMOS 16.0 is used to conduct the CFA. The CFA, also known as the measurement model, is used to assess the overall validity of 
Table 5. Factor loadings.

\begin{tabular}{cccc}
\hline & Responsiveness & Efficiency & Perceived Credibility \\
\hline Customer needs & 0.726 & & \\
Bank's accurate response & 0.754 & & \\
Bank's personalized approach & 0.694 & & \\
Help facility & 0.685 & & \\
Get in touch with the bank & 0.644 & & \\
Retrieval of information & & 0.661 & 0.721 \\
Account functionality & & 0.761 & 0.784 \\
Anytime I bank login & & 0.837 & 0.695 \\
Anywhere I bank login & & 0.779 & 0.688 \\
Unauthorized electronic fund transfer & & & 0.632 \\
Others cannot view account info & & & \\
Webpage download & & & \\
Regular update & & & \\
The visual appeal of the website & & & \\
\hline
\end{tabular}

the measures, to check whether the three-factor e-service quality fits the data set. Using CFA, the measurement model is assessed for unidimensionality, reliability, and validity. The measurement model consists of three factors: responsiveness, efficiency and perceived credibility. These factors are measured using 14 measurement items (indicators), which are derived from the exploratory factor analysis. The fit of the measurement model is assessed using eight common model-fit measures: $\chi^{2} / \mathrm{df}$, the goodness-of-fit index (GFI), the adjusted goodness-of-fit index (AGFI), the root mean square residual (RMR), the normed-fit index (NFI), the non-normed fit index (NNFI), known as the Tucker-Lewis index (TLI), the comparative fit index (CFI), and the root mean square error of approximation (RMSEA). The model fit-indices are presented in Table 6.

The results of the CFA obtained in Table 6 show that the chi-square is statistically significant $\left(\chi^{2}=148.779, \mathrm{df}=67, \mathrm{p}<0.001, \chi^{2} / \mathrm{df}=2.221\right.$ ), that is, below the cut-off point of 3 [62]. The GFI and AGFI (0.969 and 0.951) exceed the recommended cut-off point of 0.95 and 0.90 , respectively, which indicates well-fitting models [63]. The root-mean-square residual (RMR) represents the square root of the difference between the residuals of the sample covariance matrix and the hypothesized covariance model. The values of the RMR range from 0 to 1 and the well-fitting models have RMR less than 0.05 [64]. The RMR value (Table 6) is 0.044 , which is less than 0.05 , showing that the measurement model fits well. The value obtained for NFI and NNFI is 0.967 and 0.975 (Table 6), respectively, which exceeds the cut-off point. The comparative fit index (CFI) is the most popular fit index in SEM and a value of CFI $\geq 0.95$ is considered to be indicative of good fit [62]. The CFI value obtained is 0.981 (Table 6) which is above the cut-off point, indicating that the measurement model is a good fit. The root mean square error of approximation (RMSEA) with a cut-off value close to 
Table 6. Fit Indices of the Measurement Model of E-Service Quality Dimensions of Internet Banking.

\begin{tabular}{ccc}
\hline Fit Indices & Measurement Model & Cut-Off \\
\hline$\chi^{2} / \mathrm{df}$ & 2.221 & 3 \\
Goodness-of-Fit Index (GFI) & 0.969 & $\geq 0.95$ \\
Adjusted Goodness-of-Fit Index (AGFI) & 0.951 & $\geq 0.90$ \\
Root Mean Square Residual(RMR) & 0.044 & $<0.05$ \\
Normed-Fit Index(NFI) & 0.967 & $\geq 0.95$ \\
Non-Normed Fit Index(NNFI) & 0.975 & $\geq 0.95$ \\
Comparative Fit Index(CFI) & 0.981 & $\geq 0.95$ \\
Root Mean Square Error of Approximation (RMSEA) & 0.043 & $\leq 0.07$ \\
\hline
\end{tabular}

0.06 [62] or a stringent upper limit of 0.07 shows a good fit [64], and from the Table 6 the RMSEA obtained is 0.043 proves that the measurement model has a good fit of the sample data.

The model fit indices in Table 6 exceeded the common acceptance level of the fit statistics. Hence, it is confirmed that the measurement model adequately fit the data and established the three-factor structure of the e-service quality of internet banking.

After establishing the fit of the measurement model, the next step is to assess the unidimensionality of the three factors and establish the reliability and validity of a three-factor e-service quality of internet banking model. The factors (constructs) having unidimensionality with the measurement items load significantly on the underlying constructs. All the measurement items (indicators) have a significant load on their underlying constructs $(\mathrm{p}<0.01)$ with factor loadings varying between 0.611 and 0.862 (Table 7). The unstandardized regression weights are significant from the critical ratio (CR) values above \pm 1.96 (Table 7). The unidimensionality is thus established [64]. The reliability of the e-service quality dimensions is assessed by computing the composite reliability (CR) of each of the latent constructs (factors). The recommended value for the composite reliability coefficient is above 0.70 [54]. The composite reliability obtained for the three factors of e-service quality, namely, responsiveness, efficiency, and perceived credibility are $0.73,0.79$ and 0.77 , respectively (Table 7). The average variance extracted (AVE) is a complementary measure to the composite reliability, reflecting the overall amount of variance in the indicators accounted for by the latent construct [54]. The AVE value of a construct should exceed 0.50 [54], nd from Table 7, it is apparent that the AVE obtained for the construct's responsiveness (0.52), efficiency $(0.57)$ and perceived credibility (0.51) exceed the cut-off point of 0.50 .

The validity of the measurement model is established by estimating the convergent validity and discriminant validity. The convergent validity of the measurement model is estimated using the composite reliability of each construct and 
Table 7. Confirmatory factor analysis (CFA) results of e-service quality of internet banking.

\begin{tabular}{|c|c|c|c|c|c|c|}
\hline Factors & Indicators & $\begin{array}{c}\text { Standardized } \\
\text { Regression } \\
\text { Weights } \\
\text { (factor loadings) }\end{array}$ & $\begin{array}{c}\text { CR } \\
\text { (Critical } \\
\text { Ratio) }\end{array}$ & $\begin{array}{c}\mathbf{P} \\
\text { (Sig.level) }\end{array}$ & $\begin{array}{c}\text { Average } \\
\text { Variance } \\
\text { Extracted } \\
(\text { AVE) }\end{array}$ & $\begin{array}{c}\text { Composite } \\
\text { Reliability } \\
\text { (CR) }\end{array}$ \\
\hline \multirow{5}{*}{ Responsiveness } & Res1 & 0.728 & 14.88 & $* * *$ & \multirow{5}{*}{0.52} & \multirow{5}{*}{0.73} \\
\hline & Res2 & 0.688 & 14.12 & $* * *$ & & \\
\hline & Res3 & 0.629 & 13.64 & $* * *$ & & \\
\hline & Res4 & 0.637 & 15.36 & $* * *$ & & \\
\hline & Res5 & 0.699 & -----* & & & \\
\hline \multirow{4}{*}{ Efficiency } & Eff1 & 0.714 & 15.16 & $* * *$ & \multirow{4}{*}{0.57} & \multirow{4}{*}{0.79} \\
\hline & Eff2 & 0.862 & 17.08 & $* * *$ & & \\
\hline & Eff3 & 0.775 & 20.71 & $* * *$ & & \\
\hline & Eff4 & 0.661 & -----* & & & \\
\hline \multirow{5}{*}{$\begin{array}{l}\text { Perceived Cre- } \\
\text { dibility }\end{array}$} & PC1 & 0.611 & ---.-* & & \multirow{5}{*}{0.51} & \multirow{5}{*}{0.77} \\
\hline & PC2 & 0.645 & 15.33 & $* * *$ & & \\
\hline & PC3 & 0.812 & 14.75 & $* * *$ & & \\
\hline & $\mathrm{PC} 4$ & 0.821 & 14.51 & $* * *$ & & \\
\hline & PC5 & 0.718 & 13.65 & $* * *$ & & \\
\hline
\end{tabular}

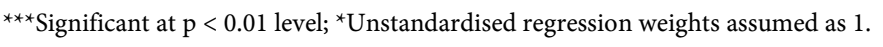

the average variance extracted by each construct. From the Table 7, it is found that the composite reliability of all three constructs was above the recommended value of 0.70 and the average variance extracted of all the three constructs exceeded the cut-off point of 0.50 [65]. The convergent validity is there by established for the three-factor structure of e-service quality of internet banking. The discriminant validity can be assessed by comparing the shared variance between the constructs and the average variance extracted from the individual constructs [65]. The CFA results reveal that the shared variance between the factors was lower than the average variance extracted from the individual factors. The discriminant validity is thus established.

\section{Relationship with E-Service Quality and Customer Satisfaction}

The e-service quality of internet banking is perceived to be an antecedent of customer satisfaction with internet banking. This study identified the e-service quality dimensions of internet banking comprising of responsiveness, efficiency and perceived credibility. Multiple regression analysis is performed to test the relationship between e-service quality dimensions and customer satisfaction with internet banking. The result is presented in the following table (Table 8).

It can be observed from Table 8 that the model is significant (F-value = 408.018, $\mathrm{p}=0.000$ ) since the $\mathrm{p}$-value is less than 0.01 . The $\mathrm{R}^{2}$ value is 0.655 , which means that all the independent variables together explained $65.5 \%$ of the 
Table 8. Multiple regression analysis with customer satisfaction with internet banking as dependent variable.

\begin{tabular}{|c|c|c|c|c|c|c|c|}
\hline \multirow{2}{*}{ Dependent Variable } & \multirow{2}{*}{ Independent Variables } & \multicolumn{2}{|c|}{$\begin{array}{l}\text { Unstandardized } \\
\text { Coefficients }\end{array}$} & \multirow{2}{*}{$\begin{array}{l}\text { Standardized } \\
\text { Coefficients } \\
\text { Beta weights }\end{array}$} & \multirow[t]{2}{*}{$\mathbf{t}$} & \multirow[t]{2}{*}{ Sig. } & \multirow[t]{2}{*}{ VIF } \\
\hline & & B & Std. Error & & & & \\
\hline \multirow{7}{*}{$\begin{array}{l}\text { Customer Satisfaction } \\
\text { with internet banking }\end{array}$} & (Constant) & 0.738 & 0.145 & & 5.095 & 0.000 & \\
\hline & Responsiveness & 0.369 & 0.029 & 0.386 & 12.694 & 0.000 & 1.728 \\
\hline & Efficiency & 0.271 & 0.028 & 0.286 & 9.566 & 0.000 & 1.670 \\
\hline & Perceived Credibility & 0.264 & 0.029 & 0.282 & 9.144 & 0.000 & 1.779 \\
\hline & F-value & \multicolumn{2}{|c|}{$\begin{array}{c}408.018^{\star *} \\
\text { p-value }=0.000\end{array}$} & & & & \\
\hline & $\mathbf{R}^{2}$ & \multicolumn{2}{|c|}{0.655} & & & & \\
\hline & AdjustedR $^{2}$ & \multicolumn{2}{|c|}{0.653} & & & & \\
\hline
\end{tabular}

"Significant $(\mathrm{p}<0.01)$.

variation in the dependent variable customer satisfaction with internet banking. It is evident that multicollinearity is not found between the independent variables, with all VIF scores less than 2 and well below the cut-off of VIF $=10$ [61]. From Table 8 , it can be seen that responsiveness $(\beta=0.386, \mathrm{t}=12.694, \mathrm{p}=$ $0.000)$, efficiency $(\beta=0.286, \mathrm{t}=9.566, \mathrm{p}=0.000)$ and perceived credibility $(\beta=$ $0.282, \mathrm{t}=9.144, \mathrm{p}=0.000)$ are statistically significant at $99 \%$ confidence level, as their $\mathrm{p}$-values are less than 0.01 . The responsiveness dimension has the highest impact on customer satisfaction since the standardized beta coefficient of responsiveness shown in Table 8 has the highest value, followed by efficiency and perceived credibility.

\section{Discussion}

The internet banking quality dimensions that emerged from the current study did not factor out the original dimensions adopted by [25], except for the perceived credibility dimension. Three new factors resulted from the research data analyzed in the present study. The results confirm that responsiveness, efficiency and perceived credibility are distinct dimensions of service quality in internet banking in India. These dimensions are consistent with the past e-service quality dimensions [12] [24] [32] and also consistent with past internet banking e-service quality studies [2] [25] [28] [29] [35] [36] [41].

The study also found that there is a positive relationship exists between e-service quality dimensions and customer satisfaction with internet banking. This result is consistent with prior research that explored the relationship between e-service quality and customer satisfaction [27] [28] [31] [34] [42]. All three dimensions have a significant positive impact on customer satisfaction. The three dimensions together explained $65.5 \%$ variance to customer satisfaction with internet banking. Among the dimensions, responsiveness has the most substantial impact, followed by efficiency and perceived credibility. Internet banking customers ranked responsiveness as the highest since customers interact 
with the bank in an online environment, where they are exposed to many fraudulent activities. Customers expect their banks to handle such situations and get prompt customer service during banking hours, as well as post-transactions. The second most important dimension is efficiency since customers expect their banks' technical expertise to conduct internet banking. This finding implies that banks should improve the service quality of internet banking with a secured website, easy to follow instructions, user-friendly interface and prompt response to the customers. Perceived credibility dimension is ranked as the third, by Indian banking customers who show the confidence they feel about their bank about internet banking. The improvement in service quality comprising of responsiveness, efficiency and perceived credibility automatically leads to customer satisfaction with internet banking services, which gives competitive advantages to the banks.

In the online environment, the customer expects an accurate response and personalized attention during and following internet banking transactions. It is imperative to give accurate, friendly and helpful customer service to internet banking users. The banking operations carried through internet banking might vary for individual customers, depending on their needs. Internet banking at present primarily facilitates traditional banking operations. Banks need to provide more comprehensive range of services through internet banking to attract more customers to use internet banking.

The internet banking website plays a crucial role in measuring the service quality of electronic banking. The customer expects a banking website to be available 24/7. The visual layout and the up-to-date information provided at the website plays a significant role in the quality of electronic banking. Banks need to understand the importance of a good website for the success of internet banking and need to concentrate on the technical functionalities of an e-banking website. Moreover, it is significant for the banks to strengthen the security measures of internet banking continuously. It is also crucial for banks to pay more attention to consumer education and consistently inform customers about security measures and policies about internet banking operations.

The findings of this study are crucial for India as well as for other Asian countries. India is at present moving towards demonetization and a cashless economy. Internet banking was optional for customers before demonetization, but the Government of India is now insisting that every bank link customer account to internet banking in order to be able to offer government services and other subsidies. The service quality dimensions identified in this study were the most important factors identified by the Indian banking customers. Moreover, the survey respondents were from all parts of India, rather than a specified city or state.

To sum up, these respondents represents both rural and urban population of India. As a result, these findings can be used by banks to improve the service quality of their internet banking service and thereby to satisfy their customers. 
The findings open up many business opportunities to India as well as other Asian countries. The digital payments industry can concentrate on improving the security of the payment systems, gateways, and payment networks. Advanced technologies can be developed to improve the digital payment systems which offer many business opportunities for creating computers, smartphones, and innovation in internet and security software. These findings are distinct compared with other studies, which concentrated on certain cities of India [66] and this study can be used as a guiding force for the digital payment industry after demonetization.

\section{Conclusions}

The objective of this study was to identify the critical dimensions of the e-service quality of internet banking as perceived by Indian banking customers and their satisfaction with internet banking. The study found a three-factor solution to the e-service quality of internet banking. The results suggest that responsiveness, efficiency and perceived credibility significantly influenced overall service quality. The most significant predictor identified is responsiveness. The study also established a positive relationship between e-service quality dimensions and customer satisfaction. The findings provide practical information useful for improving the service quality of internet banking. Commercial banks and financial institution should implement best practices in the industry in order to strengthen customers' confidence in using internet banking services.

It remains to highlight the limitations of the present study and their implications for future research. One limitation of this study is that the sampling method used is convenience sampling, which limits the study's generalizability. Another limitation is that there is a possibility that it has not captured all e-service quality dimensions. Future research can explore otherservice quality dimensions and their applicability toother technology-enabled banking services. Another potential future research area would be measuring the automated service quality and satisfaction of the self-service technologies offered by the banks.

\section{Conflicts of Interest}

The author declares no conflicts of interest regarding the publication of this paper.

\section{References}

[1] Internetworldstats.com (2017) World Internet Users Statistics and 2017 World Population Stats. http://www.internetworldstats.com/stats.htm

[2] Khan, M., Mahapatra, S. and Sreekumar, N. (2009) Service Quality Evaluation in Internet Banking: An Empirical Study in India. International Journal of Indian Culture and Business Management, 2, 30. https://doi.org/10.1504/IJICBM.2009.021596

[3] Daniel, E. (1999) Provision of Electronic Banking in the UK and the Republic of Ireland. International Journal of Bank Marketing, 17, 72-83. 
https://doi.org/10.1108/02652329910258934

[4] Jayawardhena, C. and Foley, P. (2000) Changes in the Banking Sector-The Case of Internet Banking in the UK. Internet Research, 10, 19-31.

https://doi.org/10.1108/10662240010312048

[5] Pikkarainen, K., Pikkarainen, T., Karjaluoto, H. and Pahnila, S. (2006) The Measurement of End-User Computing Satisfaction of Online Banking Services: Empirical Evidence from Finland. International Journal of Bank Marketing, 24, 158-172. https://doi.org/10.1108/02652320610659012

[6] Aladwani, A. (2001) Online Banking: A Field Study of Drivers, Development Challenges, and Expectations. International Journal of Information Management, 21, 213-225. https://doi.org/10.1016/S0268-4012(01)00011-1

[7] Enders, A. and Jelassi, T. (2000) The Converging Business Models of Internet and Bricks-and-Mortar Retailers. European Management Journal, 18, 542-550. https://doi.org/10.1016/S0263-2373(00)00043-8

[8] Chau, P. and Lai, V. (2003) An Empirical Investigation of the Determinants of User Acceptance of Internet Banking. Journal of Organizational Computing and Electronic Commerce, 13, 123-145. https://doi.org/10.1207/S15327744JOCE1302_3

[9] Malhotra, P. and Singh, B. (2007) Determinants of Internet Banking Adoption by Banks in India. Internet Research, 17, 323-339. https://doi.org/10.1108/10662240710758957

[10] Boston Consulting Group and Google India (2016) Digital Payments 2020. Boston Consulting Group and Google India, Mumbai, 1-56.

[11] IBEF (2016) Banking. IBEF, Mumbai. http://www.ibef.org

[12] Zeithaml, V. (2002) Service Excellence in Electronic Channels. Managing Service Quality: An International Journal, 12, 135-139. https://doi.org/10.1108/09604520210429187

[13] Fassnacht, M. and Koese, I. (2006) Quality of Electronic Services. Journal of Service Research, 9, 19-37. https://doi.org/10.1177/1094670506289531

[14] Gummerus, J., Liljander, V., Pura, M. and van Riel, A. (2004) Customer Loyalty to Content-Based Web Sites: The Case of an Online Health-Care Service. Journal of Services Marketing, 18, 175-186. https://doi.org/10.1108/08876040410536486

[15] Van Riel, A., Liljander, V. and Jurriëns, P. (2001) Exploring Consumer Evaluations of e-Services: A Portal Site. International Journal of Service Industry Management, 12, 359-377. https://doi.org/10.1108/09564230110405280

[16] Barrutia, J. and Gilsanz, A. (2009) e-Service Quality: Overview and Research Agenda. International Journal of Quality and Service Sciences, 1, 29-50. https://doi.org/10.1108/17566690910945859

[17] Yoo, B. and Donthu, N. (2001) Developing a Scale to Measure the Perceived Quality of an Internet Shopping Site (Sitequal). Quarterly Journal of Electronic Commerce, 31-46.

[18] Barnes, S. and Vidgen, R. (2002) An Integrative Approach to the Assessment of E-Commerce Quality. Journal of Electronic Commerce Research, 3, 114-127.

[19] Loiacono, E., Watson, R. and Goodhue, D. (2002) WebQual: A Measure of Website Quality. Marketing Theory and Applications, 13, 432-438.

[20] Palmer, J. (2002) Web Site Usability, Design, and Performance Metrics. Information Systems Research, 13, 151-167. https://doi.org/10.1287/isre.13.2.151.88

[21] Webb, H. and Webb, L. (2004) SiteQual: An Integrated Measure of Web Site Quality. Journal of Enterprise Information Management, 17, 430-440. 
https://doi.org/10.1108/17410390410566724

[22] Kim, M., Kim, J. and Lennon, S. (2006) Online Service Attributes Available on Apparel Retail Web Sites: An E-S-QUAL Approach. Managing Service Quality: An International Journal, 16, 51-77. https://doi.org/10.1108/09604520610639964

[23] Lin, H. (2007) The Impact of Website Quality Dimensions on Customer Satisfaction in the B2C E-Commerce Context. Total Quality Management \& Business Excellence, 18, 363-378. https://doi.org/10.1080/14783360701231302

[24] Parasuraman, A., Zeithaml, V. and Malhotra, A. (2005) E-S-QUAL. Journal of Service Research, 7, 213-233. https://doi.org/10.1177/1094670504271156

[25] Jayawardhena, C. (2004) Measurement of Service Quality in Internet Banking: The Development of an Instrument. Journal of Marketing Management, 20, 185-207. https://doi.org/10.1362/026725704773041177

[26] Han, S. and Baek, S. (2004) Antecedents and Consequences of Service Quality in Online Banking: An Application of the SERVQUAL Instrument. Advances in Consumer Research, 31, 208-214.

[27] Punyani, G., Dash, G. and Sharma, S. (2015) An Assessment of Customers' Service Quality Perception through Webqual Scale: A Study on Online Banking Services. Researchers World, 6, 106.

[28] Siu, N. and Mou, J. (2005) Measuring Service Quality in Internet Banking. Journal of International Consumer Marketing, 17, 99-116. https://doi.org/10.1300/J046v17n04_06

[29] Zavareh, F., Ariff, M., Jusoh, A., Zakuan, N., Bahari, A. and Ashourian, M. (2012) E-Service Quality Dimensions and Their Effects on e-Customer Satisfaction in Internet Banking Services. Procedia-Social and Behavioral Sciences, 40, 441-445. https://doi.org/10.1016/j.sbspro.2012.03.213

[30] Jun, M. and Cai, S. (2001) The Key Determinants of Internet Banking Service Quality: A Content Analysis. International Journal of Bank Marketing, 19, 276-291. https://doi.org/10.1108/02652320110409825

[31] Rod, M., Ashill, N., Shao, J. and Carruthers, J. (2009) An Examination of the Relationship between Service Quality Dimensions, Overall Internet Banking Service Quality and Customer Satisfaction. Marketing Intelligence \& Planning, 27, 103-126. https://doi.org/10.1108/02634500910928344

[32] Yang, Z. and Jun, M. (2002) Consumer Perception of E-Service Quality: From Internet Purchaser and Non-Purchaser Perspectives. Journal of Business Strategies, $25,60-84$.

[33] Ibrahim, E., Joseph, M. and Ibeh, K. (2006) Customers' Perception of Electronic Service Delivery in the UK Retail Banking Sector. International Journal of Bank Marketing, 24, 475-493. https://doi.org/10.1108/02652320610712094

[34] Santouridis, I., Trivellas, P. and Reklitis, P. (2009) Internet Service Quality and Customer Satisfaction: Examining Internet Banking in Greece. Total Quality Management \& Business Excellence, 20, 223-239. https://doi.org/10.1080/14783360802623084

[35] White, H. and Nteli, F. (2004) Internet Banking in the UK: Why Are There Not More Customers? Journal of Financial Services Marketing, 9, 49-56. https://doi.org/10.1057/palgrave.fsm.4770140

[36] Sohail, S. and Shaikh, N. (2008) Internet Banking and Quality of Service. Online Information Review, 32, 58-72. https://doi.org/10.1108/14684520810865985

[37] Bauer, H., Hammerschmidt, M. and Falk, T. (2005) Measuring the Quality of 
E-Banking Portals. International Journal of Bank Marketing, 23, 153-175. https://doi.org/10.1108/02652320510584395

[38] Sohn, C. and Tadisina, S. (2008) Development of E-Service Quality Measure for Internet-Based Financial Institutions. Total Quality Management \& Business Excellence, 19, 903-918. https://doi.org/10.1080/14783360802224412

[39] Al-Hawari, M., Hartley, N. and Ward, T. (2005) Measuring Banks' Automated Service Quality: A Confirmatory Factor Analysis Approach. Marketing Bulletin, 16, $1-19$.

[40] Ho, C. and Lin, W. (2010) Measuring the Service Quality of Internet Banking: Scale Development and Validation. European Business Review, 22, 5-24. https://doi.org/10.1108/09555341011008981

[41] Al-Tarawneh, K. (2012) Measuring E-Service Quality from the Customers' Perspective: An Empirical Study on Banking Services. International Research Journal of Finance and Economics, 91, 123-137.

[42] Herington, C. and Weaven, S. (2009) E-Retailing by Banks: E-Service Quality and Its Importance to Customer Satisfaction. European Journal of Marketing, 43, 1220-1231. https://doi.org/10.1108/03090560910976456

[43] Oliver, R. (1996) Satisfaction: A Behavioral Perspective on the Consumer. McGrawHill Companies, New York.

[44] Anderson, R. and Srinivasan, S. (2003) E-Satisfaction and E-Loyalty: A Contingency Framework. Psychology and Marketing, 20, 123-138.

https://doi.org/10.1002/mar.10063

[45] DeLone, W. and McLean, E. (2003) The DeLone and McLean Model of Information Systems Success: A Ten-Year Update. Journal of Management Information Systems, 19, 9-30. https://doi.org/10.1080/07421222.2003.11045748

[46] Cronin, J. and Taylor, S. (1992) Measuring Service Quality: A Reexamination and Extension. Journal of Marketing, 56, 55. https://doi.org/10.1177/002224299205600304

[47] Collier, J. and Bienstock, C. (2006) Measuring Service Quality in E-Retailing. Journal of Service Research, 8, 260-275. https://doi.org/10.1177/1094670505278867

[48] Cristobal, E., Flavián, C. and Guinalíu, M. (2007) Perceived E-Service Quality (PeSQ). Managing Service Quality. An International Journal, 17, 317-340. https://doi.org/10.1108/09604520710744326

[49] Carlson, J. and O'Cass, A. (2010) Exploring the Relationships between E-Service Quality, Satisfaction, Attitudes and Behaviours in Content-Driven E-Service Web Sites. Journal of Services Marketing, 24, 112-127. https://doi.org/10.1108/08876041011031091

[50] Saunders, S. and Petzer, D. (2010) The Interrelationship between Service Quality, Satisfaction and Behavioural Intention by Customer Stage in the Service Delivery Process. Management Dynamics, 19, 25-34.

[51] Parasuraman, A., Zeithaml, V. and Berry, L. (1988) SERVQUAL: A Multiple-Item Scale for Measuring Consumer Perceptions of Service Quality. Journal of Retailing, 12-40.

[52] Yang, Z., Jun, M. and Peterson, R.T. (2004) Measuring Customer Perceived Online Service Quality: Scale Development and Managerial Implications. International Journal of Operations \& Production Management, 24, 1149-1174. https://doi.org/10.1108/01443570410563278

[53] Krosnick, J. and Presser, S. (2010) Question and Questionnaire Design. Handbook 
of Survey Research, 2, 263-314.

[54] Hair, J., Black, W., Babin, B. and Anderson, R. (2006) Multivariate Data Analysis. 5th Edition, Pearson Education Limited, Harlow.

[55] Nunnally, J. and Bernstein, I. (1978) Psychometric Theory. Tata McGraw-Hill Ed., New Delhi.

[56] Hinkin, T. (1998) A Brief Tutorial on the Development of Measures for Use in Survey Questionnaires. Organizational Research Methods, 1, 104-121. https://doi.org/10.1177/109442819800100106

[57] Podsakoff, P.M., MacKenzie, S.B., Lee, J.Y. and Podsakoff, N.P. (2003) Common Method Biases in Behavioral Research: A Critical Review of the Literature and Recommended Remedies. Journal of Applied Psychology, 88, 879. https://doi.org/10.1037/0021-9010.88.5.879

[58] Laforet, S. and Li, X. (2005) Consumers' Attitudes towards Online and Mobile Banking in China. International Journal of Bank Marketing, 23, 362-380. https://doi.org/10.1108/02652320510629250

[59] Laukkanen, T. and Pasanen, M. (2008) Mobile Banking Innovators and Early Adopters: How They Differ from Other Online Users? Journal of Financial Services Marketing, 13, 86-94. https://doi.org/10.1057/palgrave.fsm.4760077

[60] Ainin, S., NoorIsmawati, J. and Mohezar, S. (2007) An Overview of Mobile Banking Adoption among the Urban Community. International Journal of Mobile Communications, 5, 157-168. https://doi.org/10.1504/IJMC.2007.011814

[61] Field, A. (2009) Discovering Statistics Using SPSS. 3rd Edition, Sage Publications, London.

[62] Hu, L. and Bentler, P. (1999) Cutoff Criteria for Fit Indexes in Covariance Structure Analysis: Conventional Criteria versus New Alternatives. Structural Equation Modeling: A Multidisciplinary Journal, 6, 1-55.

https://doi.org/10.1080/10705519909540118

[63] Hooper, D., Coughlan, J. and Mullen, M. (2008) Structural Equation Modeling: Guidelines for Determining Model Fit. The Electronic Journal of Business Research Methods, 6, 53-60.

[64] Byrne, B. (1998) Structural Equation Modeling with LISREL, PRELIS, and SIMPLIS: Basic Concepts, Applications, and Programming.

[65] Fornell, C. and Larcker, D. (1981) Evaluating Structural Equation Models with Unobservable Variables and Measurement Error. Journal of Marketing Research, 18, 39. https://doi.org/10.1177/002224378101800313

[66] Kaura, V., Durga Prasad, C.S. and Sharma, S. (2015) Service Quality, Service Convenience, Price and Fairness, Customer Loyalty, and the Mediating Role of Customer Satisfaction. International Journal of Bank Marketing, 33, 404-422. https://doi.org/10.1108/IJBM-04-2014-0048 